\title{
ARTIGO
}

\section{EVALUATION OF SURFACE TEMPERATURE OF TONGUE FOR SCREENING OF PATIENTS WITH SUSPECTED ORAL CANCER ${ }^{1}$}

\author{
Amanda Isabella Abreu \\ Thiago Parente Lima \\ Agnes Batista Meireles \\ Bárbara Emanuella Souza \\ Libardo Andrés González Torres
}

\begin{abstract}
Oral cancer has become one of the most critical types of cancer today due to its late diagnosis in Brazil. The early detection is mandatory for more favorable prognosis but it depends on patient's information, specialized infrastructure and trained professionals not always available. The use of thermographic imaging becomes a viable alternative for patient screening and triage in different areas. This is a non-invasive and low-cost procedure, especially when compared to the main imaging tests such as magnetic resonance imaging and computed tomography. Thus, the aim of this work was to develop a computational model capable of representing the thermal behavior on the surface of the tongue tissue in the presence or absence of malignant neoplasms. The obtained results did not show changes in the temperature profile of the tissue when a small tumor (up to $2 \mathrm{~mm}$ in radius) is present. It can be concluded that it is not possible to detect a tumor in the tongue through a thermal analysis on the surface with thermographic images, due to the low differences obtained. However, other conditions for the model and also tumors in other locations should be studied in order to obtain more general conclusions.
\end{abstract}

Keywords: Oral cancer. Thermography. Screening. Infrared images.

\section{INTRODUCTION}

In Brazil, only $20 \%$ of tumors are detected in early stages and the other $80 \%$ are diagnosed in more advanced stages (CAMARGO, 2017). This contrasts with the concept that the earlier the diagnosis, the greater the chances of cure and better is the patient's quality of life (MINISTÉRIO DE SAÚDE, 2006). Particularly, according to the National Cancer Institute, oral cancer is often diagnosed late. More than 14.000 new cases of oral cancer are

\footnotetext{
${ }^{1}$ Como citar este artigo: ABREU, Amanda Isabella; LIMA, Thiago Parente; MEIRELES, Agnes Batista; SOUZA, Bárbara Emanuella; TORRES, Libardo Andrés Gonzáles. Evaluation of surface temperature of tongue for screening of patients with suspected oral cancer. ForScience: revista científica do IFMG, Formiga, v. 7, n. 2, e00639, jul./dez. 2019. DOI: 10.29069/forscience.2019v7n2.e639.
}

${ }^{2}$ Autor para correspondência: Amanda Isabella Abreu, e-mail: amanda.isabella.abreu@gmail.com. 
registered in Brazil, being the majority among men, which makes it a relevant public health problem with reported more than 4 thousand deaths/year (CRO-GO, 2017). This type of cancer is also reported among the three most common in developing countries (CAMARGO, 2017).

Some important factors associated with this disease are the patient's life habits, such as alcohol and tobacco consumption, and individual social issues, such as the lack of information about the disease. The sites with the highest incidence of oral cancer are tongue (26\%), lips $(23 \%)$, especially on the lower-lip, sublingual region (16\%) and minor salivary glands (11\%). The rest are found in the gums and other locations. These cancers may occur in all age groups but are rare in children. Approximately two-thirds of the patients are older than 55 years old (MADEIRA; LEITE; RIZZOLO, 2016; CAMARGO, 2017). Clinical examination itself is not enough to detect the extent of the tumor and the presence of cervical metastases. Computed tomography (CT) and magnetic resonance imaging (MRI) are the main tests used for diagnosis. However, both are high-cost techniques, and during CT the patient is submitted to ionizing radiation (PAIVA, 2009). The most accurate diagnosis of oral cancer is a biopsy, which is an invasive procedure that can generate false negatives if the tissue collected is not that of the cancerous region (CHAKRABORTY, 2016).

Thus, it is evident a deficiency on tools for the early detection of the disease (CHAKRABORTY, 2016). This difficulty could be overcome with the use of thermographic images, an alternative to assist by screening patients with suspected cancer. Thermography is a technique that uses specialized cameras to visualize and measure the temperature of a surface. The technique has been used in medicine as it is able of detecting, in real time, changes in temperature patterns related to inflammatory processes as well as endocrine and oncological conditions (SCHWARTZ et al., 2006; FERNÁNDEZ-CUEVAS et al., 2015; HADDAD, 2016).

Tumors arise from the uncontrolled development of malignant cells in the body, resulting in increased blood perfusion in the affected region, which causes an increase in local temperature. This temperature increase has the potential to be detected in thermographic images produced by the thermography technique (SILVA, 2015). In addition, changes in tumor temperature over time may support the definition of treatment strategies (COHEN, 2013).

In this context, the aim of this work is to develop a computational model to represent the temperature behavior on the surface of the tongue in the presence of tumors of different 
sizes. This research intends to verify if the presence of a tumor, in its early stages, can be detected through thermographic images.

\section{DEVELOPMENT}

\subsection{BIOHEAT TRANSFER MODELS}

In the presence of a temperature difference between medias or within a medium, the transfer of energy occurs in the form of heat. This transfer can occur by different means: conduction, convection and radiation. Conduction occurs due to the existence of a temperature gradient in solids or fluids in stationary medium. Convection occurs when there is a temperature difference between a surface and a moving fluid. Finally, the thermal radiation is the emission of energy in the form of electromagnetic waves (INCROPERA; DE WITT, 2008; MOREIRA, 2012).

\subsubsection{Pennes’ Model}

The most widely used equation for describing heat transfer in living tissues was developed by Harry H. Pennes (1948) known as the Bioheat Transfer or Pennes Equation. The Pennes equation describes the temporal and spatial distribution of temperature in living beings and, although it carries some limitations, this model is very useful for this type of heat transfer analysis (SILVA, 2012).

The arrangement of this equation was made from the energy balance, considering the rate of internal energy storage, heat exchange by conduction and convection, the local generation of heat and neglecting the chemical, physical, nuclear and electrical effects. The solid, linear, homogeneous biological medium with isotropic thermal properties is considered to obtain the temperature field. The convective heat exchange will only occur in the capillary system. It is assumed, for the energy balance, that the blood flow inside the tissue is nondirectional to the capillary level. Therefore, it will be adopted that the capillaries are oriented according to their arteriolar and venular connections (BEZERRA, 2007). The Equation (1) is the result of energy balance on a tissue with blood flow, metabolic heat generation and an external heat source (SILVA, 2012). 


$$
\rho_{t} c_{t} \frac{\partial T_{t}}{\partial t}=\nabla\left(k_{t} \nabla T_{t}\right)+Q_{m}+Q_{p}+Q_{\varepsilon}
$$

Where $\rho_{t}$ is the tissue density $\left(\mathrm{kgm}^{-3}\right), \mathrm{c}_{\mathrm{t}}$ is the tissue specific heat $\left(\mathrm{Jkg}^{-1} \mathrm{~K}^{-1}\right), \mathrm{T}_{\mathrm{t}}$ is the tissue temperature $(\mathrm{K}), \mathrm{t}$ is the time $(\mathrm{s}), \mathrm{k}_{\mathrm{t}}$ the thermal conductivity of the tissue $\left(\mathrm{Wm}^{-1} \mathrm{~K}^{-1}\right)$, $\mathrm{Q}_{\mathrm{m}}$ is the rate of metabolic heat generation per unit of volume $\left(\mathrm{Wm}^{-3}\right), \mathrm{Q}_{\mathrm{p}}$ is the rate of heat generation or withdraw per unit of volume due to blood perfusion $\left(\mathrm{Wm}^{-3}\right)$ and $\mathrm{Q}_{\mathrm{e}}$ is the rate of heat generation per unit of volume due to external sources $\left(\mathrm{Wm}^{-3}\right)$.

Pennes' theory proposes that the heat transfer caused by the blood flow can be described by a blood perfusion rate as a scalar heat source or sink (SILVA, 2012). This heat source or sink can be described according Equation (2):

$$
Q_{p}=\omega \rho_{b} c_{b}\left(T_{a}-T_{v}\right)
$$

where $\omega$ is the blood perfusion rate $\left(\mathrm{s}^{-1}\right), \rho_{\mathrm{b}}$ is the blood density $\left(\mathrm{kgm}^{-3}\right), \mathrm{c}_{\mathrm{b}}$ is the specific heat of the blood $\left(\mathrm{Jkg}^{-1} \mathrm{~K}^{-1}\right), \mathrm{T}_{\mathrm{a}}$ is the arterial blood temperature entering the tissue $(\mathrm{K})$ and $\mathrm{T}_{\mathrm{v}}$ is the venous blood temperature entering the tissue $(\mathrm{K})$.

If the thermal equilibrium between the blood and local tissue is considered, $\mathrm{T}_{\mathrm{v}}=\mathrm{T}_{\mathrm{t}}$, also it is often considered that the venous blood leaves the tissue with the temperature of the arterial blood, thus $T_{v}=T_{a}$ (BEZERRA, 2007).

\subsubsection{Limited keff model}

In the limited keff model, the blood flow of smaller vessels is described using the tissue conductivity keff in the first term of the right hand side of Equation (3), which represents the tissue conduction and convection (CREZEE, 1994; PARK; ALONSO; NUNES, 1999).

$$
\rho_{t} c_{t} \frac{\partial T_{t}}{\partial t}=k_{e f f} \nabla^{2} T_{t}+Q_{p}+Q_{m}+Q_{s}
$$

The effective tissue conductivity coefficient $k_{\text {eff }}$ depends on vessel size, velocity of flow and vascular structure, and reduces to a scalar for isotropic flow. The limitation of this model is that it only applies to vessels with a diameter smaller than $500 \mu \mathrm{m}$ (CREZEE, 1994).

\subsubsection{Mixed Model}


The mixed model is suggested when there is the presence of thermally unbalanced vessels larger than $500 \mu \mathrm{m}$. The model has the advantage of being applied in situations where there is no information about the actual vascular anatomy (CREZEE, 1994). The mixed model is the combination of the Pennes' model and the limited $k_{\text {eff }}$ with the addition of the modifying factor $f$ in the term $\mathrm{Q}_{\mathrm{p}}$ :

$$
Q_{p}=f \omega \rho_{b} c_{b}\left(T_{a}-T_{v}\right)
$$

the modifying factor $f$ of the heat source/sink term, depends on the local vessel network. For a closed vessel system $0 \leq f \leq 1$ (CREZEE, 1994). Since the mixed model improves on previous models while keeping its simplicity, it will be adopted in this study.

\subsection{MATHEMATICAL MODELING}

A three-dimensional model was performed to determine the distribution of temperature in a human tongue in the presence of a tumor. Tongue dimensions were collected from the authors of this study. The simplified geometry of the model was based on the shape of the tongue (SANDERS; MU, 2013) and built in the software COMSOL Multiphysics ${ }^{\circledR} 5.1$ and is shown in Figure 1. The tumor was positioned in the lateral border of the tongue, near its base, which is the region of higher incidence of this type of cancer (HIROTA; MIGLIARI; SUGAYA, 2006; MADEIRA et al., 2016). The tumor was represented as a sphere of different diameters, all located at $0.5 \mathrm{~mm}$ from the lateral surface of the tongue.

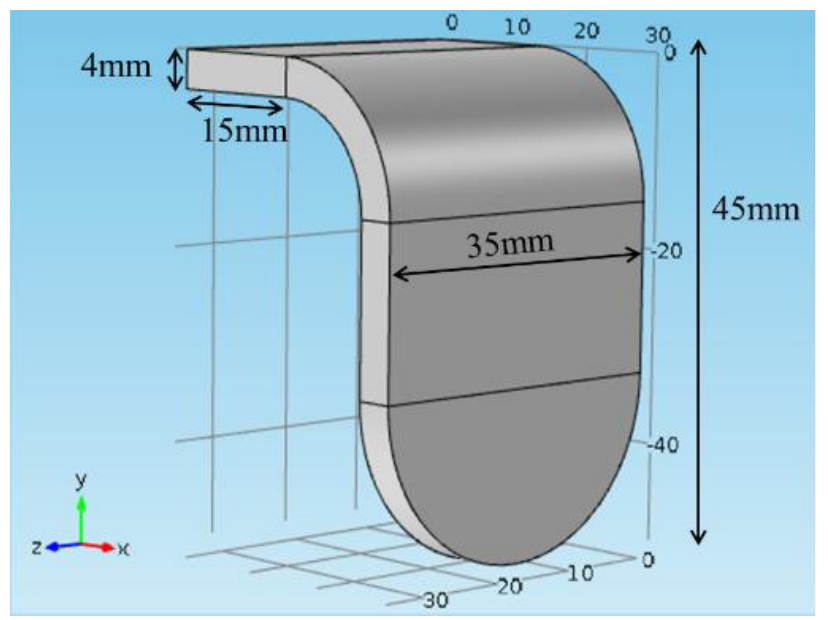

Figure 1 - Geometry of the tongue used in the computational model Source: Own author. 
The temperature distribution in the tongue and tumor were modeled according Equation (5) which consider the mixed model without external heat sources and with $f=1$.

$$
\rho_{t} c_{t} \frac{\partial T_{t}}{\partial t}=k_{e f f} \nabla^{2} T_{t}-f \omega \rho_{s} c_{s}\left(T_{t}-T_{a}\right)+Q_{m}
$$

\subsubsection{Boundary conditions}

To establish the boundary conditions, it was considered that the tongue is initially at rest inside the oral cavity and the mouth of the patient is closed for such a period of time that the temperatures on the surface of the tongue were stable. Additionally, the images of the thermographic camera were obtained immediately after the tongue is placed out of the mouth, so no considerable heat exchanges between the organ and the environment.

In order to reproduce the environment of the oral cavity, boundary conditions of constant temperature and heat flux were set to the surfaces of the tongue. The body temperature of $37^{\circ} \mathrm{C}$ were considered on the surface of the base of the tongue. On the sublingual region, the sublingual temperature of $36.6{ }^{\circ} \mathrm{C}$ were considered (LÓPEZ; LAURENTYS-MEDEIROS, 2004). For the rest of the tongue surfaces, a conduction heat flux trough a saliva film was considered between the lateral and the top surfaces of the tongue and the air inside the oral cavity. The heat flux is described by the Equation (6):

$$
q=U\left(T_{\text {oral }}-T\right)
$$

where $U=k_{\text {saliva }} / \mathrm{L}$ is the global coefficient of heat transfer, $k_{\text {saliva }}(\mathrm{W} / \mathrm{mK})$ is the thermal conductivity of the saliva, $\mathrm{L}(\mathrm{m})$ is the thickness of the saliva film, $\mathrm{T}_{\text {oral }}(\mathrm{K})$ is the temperature of the air inside the oral cavity and $\mathrm{T}(\mathrm{K})$ is the temperature of the surface of the tongue. The thickness of the saliva film was considered as L=0.085 mm (COLLINS; DAWES, 1987).

\subsubsection{Physical properties and model parameters}

There is a lack of data in the literature regarding the physical properties of tongue tumors, thus properties of the breast tumor were used during the simulations that are widely reported in the literature. The rate of metabolic heat generation on an early stage tumor is much higher than on advanced stages due to the large amount of blood vessels formed in the 
region (COIMBRA et al., 2011). This rate decreases as the tumor grows. Tumors up to $10 \mathrm{~mm}$ and $30 \mathrm{~mm}$ have a metabolic heat rate of $65400 \mathrm{Wm}^{-3}$ and $5740 \mathrm{Wm}^{-3}$, respectively (BEZERRA, 2007). As the study aims to reproduce a diagnosis on an early stage, the rate of heat generation was considered constant at $65400 \mathrm{Wm}^{-3}$.

Table 1 shows the physical properties considered in the model. The properties of the saliva were approximate to the water due to its high content of water, 99\% (DE MOURA et al., 2007). The remaining properties are $k_{\text {eff }}=1.8\left(\mathrm{~W}^{\circ} \mathrm{C}^{-1} \mathrm{~m}^{-1}\right)(\mathrm{CREZEE}, 1994), \mathrm{T}_{\mathrm{a}}=37\left({ }^{\circ} \mathrm{C}\right)$ and $\mathrm{T}_{\text {oral }}=34.4^{\circ} \mathrm{C}$ as measured by the authors.

Table 1 - Physical properties

\begin{tabular}{ccccc}
\hline Property & Tongue & Blood $^{(\mathbf{a})}$ & Saliva $^{(\mathbf{a})}$ & Tumor $^{(\mathbf{b})}$ \\
\hline Heat generation rate, $\mathrm{Q}\left(\mathrm{Wm}^{-3}\right)$ & $\begin{array}{c}1.21 \times 10^{3} \\
(\mathrm{a})\end{array}$ & - & - & 65400 \\
Density, $\rho\left(\mathrm{kgm}^{-3}\right)$ & $1090^{(\mathrm{a})}$ & 1050 & 994 & 1080 \\
Specific heat, $\mathrm{c}_{\mathrm{t}}\left(\mathrm{J} \mathrm{kg}^{-1} \mathrm{~K}^{-1}\right)$ & $3421^{(\mathrm{a})}$ & 3617 & 4178 & 3500 \\
Thermal conductivity, $\mathrm{k}_{\mathrm{t}}\left(\mathrm{Wm}^{-1} \mathrm{~K}^{-1}\right)$ & $0.49^{(\mathrm{a})}$ & 0.52 & 0.6 & 0.48 \\
Blood perfusion rate, $\omega\left(\mathrm{s}^{-1}\right)$ & $0.0018^{(\mathrm{c})}$ & - & - & 0.009 \\
\hline
\end{tabular}

Source: (a) It is Foundation (2018), (b) Bezerra (2007) and (c) Crezee et al. (1994).

\subsubsection{Numerical procedure}

The steady state form of Equation (5) and its boundary conditions were implemented in the software COMSOL Multiphysics ${ }^{\circledR} 5.1$ and solved through the Finite Element Method (DE SOUZA, 2003). The mesh independence study was performed with meshes of 8815, 33930 and 161833 tetrahedral elements. The temperature of three points on the external surface of the tumor were monitored for the three meshes. This region was chosen because it presents the steeper temperature gradients of the domain. The maximum temperature difference between the meshes was of $3 \times 10^{-4} \%$, thus, the solution was considered mesh independent. Since the difference in computational time between the first and the second meshes was negligible, the second mesh of 33930 elements were chosen for this study.

\subsection{RESULTS AND DISCUSSION}

ForSci.: r. cient. IFMG, Formiga, v. 7, n. 2, e00639, jul./dez. 2019. 
The tumor was included in the region of higher incidence, which is the upper lateral border (HIROTA, 2006) and its diameter varied between 1.0 and $4.0 \mathrm{~mm}$ sizes, difficult to detect by visual inspection. Simulations were performed for a healthy tongue (no tumor), and with tumor to estimate the surface temperature. All tumors were located at a distance of 0.5 $\mathrm{mm}$ from the extremity of the upper lateral border of the tongue. For better visualization, two images were generated: one of the surfaces of the tongue and other of a transversal section passing by the center of the tumor.

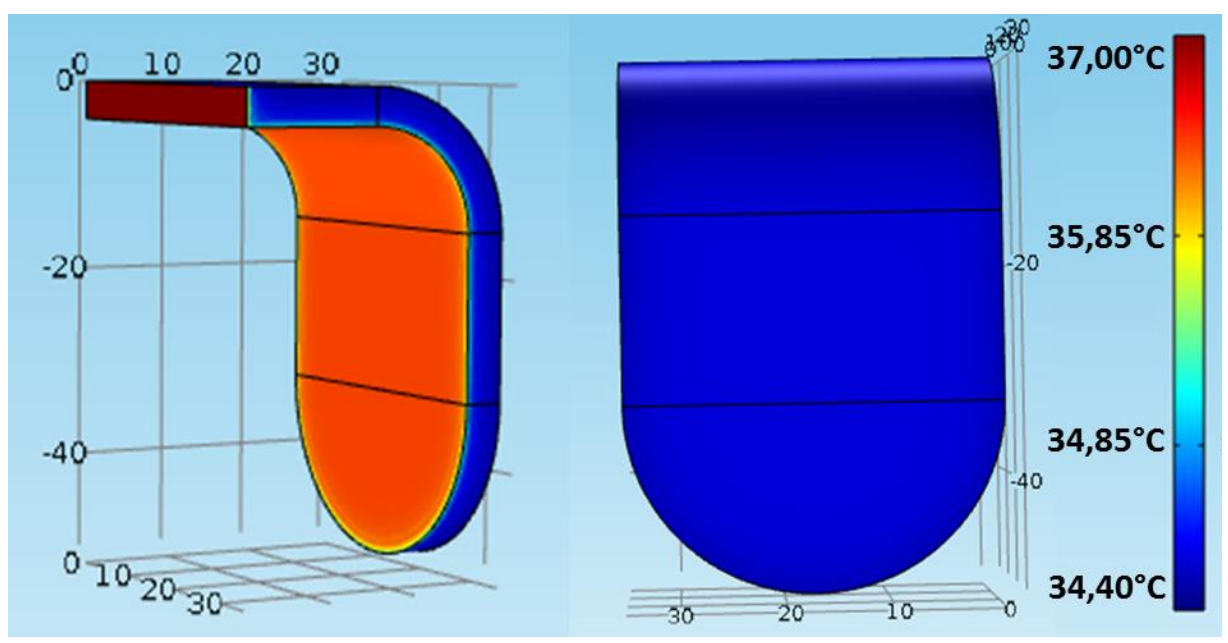

Figure 2 - Healthy tongue Source: Own author.

After performing the simulations for the chosen case studies, we have extracted some relevant results. The temperature on the surface of the healthy tongue varied between $34.40^{\circ} \mathrm{C}$ and $37.00{ }^{\circ} \mathrm{C}$ (Figure 2) which corresponds to the body temperature previously reported in the literature (SILVA, 2012). The side edges and upper part of the tongue lose more heat because the air temperature inside the oral cavity is lower than the sublingual temperature and the body temperature. This generates a greater temperature difference between the media and a higher heat transfer flux.

Figure 3 shows the lateral views (a) and in a transversal section at the center of the tumor (b). 


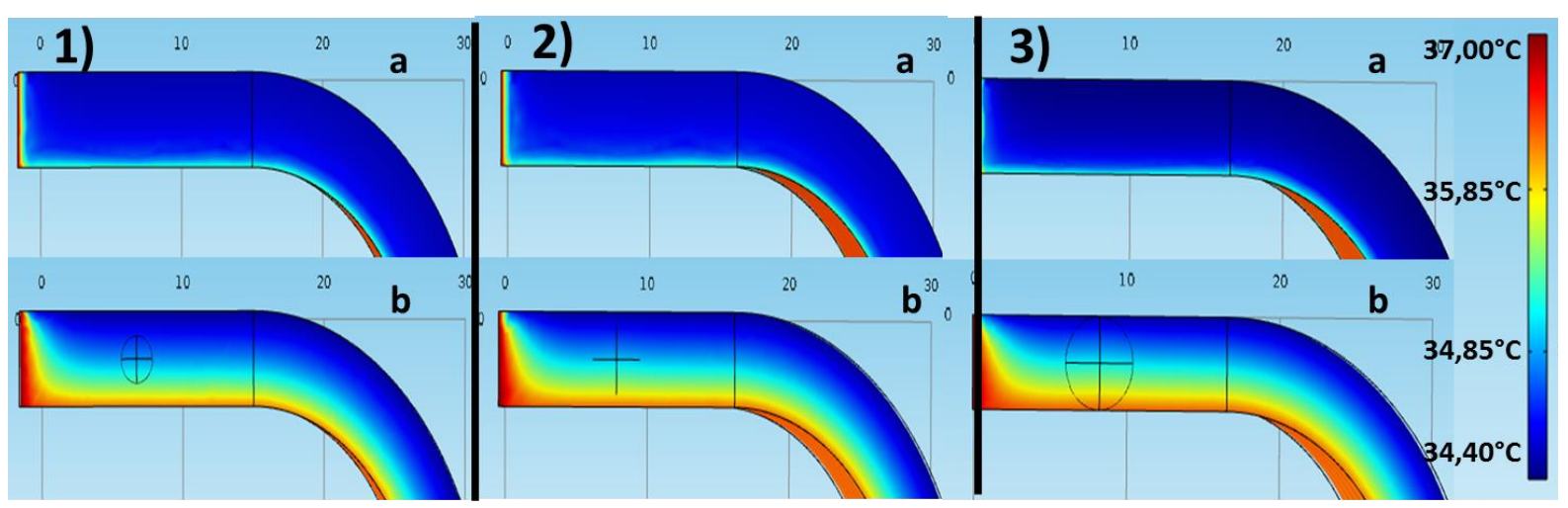

Figure 3 - Temperature distribution on the tongue with tumors of various sizes: 1) $1.0 \mathrm{~mm}$ radius 2) $1.5 \mathrm{~mm}$ radius 3) $2.0 \mathrm{~mm}$ radius

Source: Own author

Temperature profile was not modified in the region where the tumor is inserted in any of the cases. Thus, there were not changes in the surface profile with the presence of a tumor up to $2.0 \mathrm{~mm}$ of diameter. The temperature at the center of the tumor was close to the temperatures used in the boundary conditions, $35.4{ }^{\circ} \mathrm{C}$ (air inside the mouth) and $36.6{ }^{\circ} \mathrm{C}$ (sublingual region).

In order to estimate how the temperature patterns would change if the tumor generated a much larger amount of heat, simulations were made with the heat generation rate of the tumor artificially increased by 100 times. With this increase, it is possible to detect the temperature variation in the tumor region (Figure 4), where (a) represent the surface of the tongue and (b) a cut at the center of the tumor.

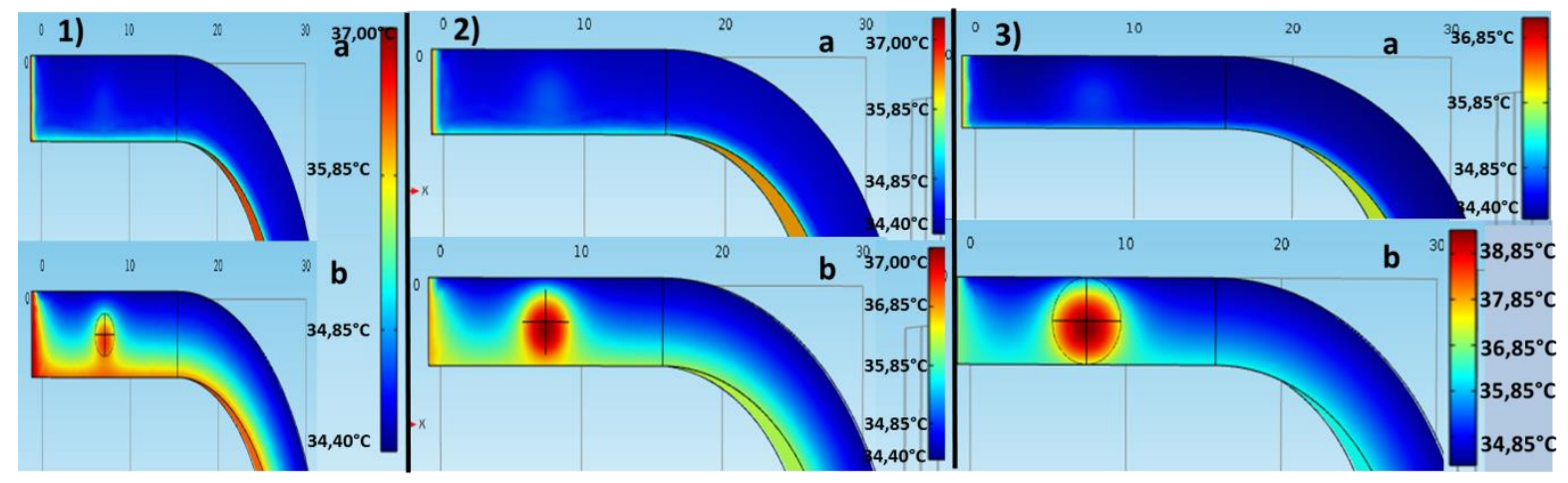

Figure 4 - Temperature of the tongue with increase by 100 times in the heat generation rate of the tumor. 1) Tumor of $1.0 \mathrm{~mm}$ radius; 2) tumor of $1.5 \mathrm{~mm}$ radius; 3 ) tumor of $2.0 \mathrm{~mm}$ radius Source: Own author 
The temperatures at the center of the tumor are presented in Table 3:

Table 2 - Temperature at the center of the tumor with the increase of $Q_{m}$ by 100 times

\begin{tabular}{ccc} 
Radius of the tumor $(\mathrm{mm})$ & $\begin{array}{c}\text { Tumor temperature }\left({ }^{\circ} \mathrm{C}\right) \\
\text { Tumor temperature with } \\
\text { increased heat generation rate } \\
\text { by } 100 \text { times }\left({ }^{\circ} \mathrm{C}\right)\end{array}$ \\
\hline 1.0 & 34.95 & 36.32 \\
1.5 & 35.10 & 37.69 \\
2.0 & 35.23 & 39.28 \\
\hline
\end{tabular}

It can be observed that the increase in the heat generation rate of the tumor does not meet the real patterns as expected. A tumor able of generating such heat would be easily noticed by the patients due to their very high temperatures present by the tissue. However, such increase demonstrated that a much higher heat generation rate would be necessary to allow the detections of a tumor by thermographic images. This higher heat generation would produce a greater difference between the temperatures of the boundary conditions and the tumor, making the temperature pronounced and facilitating the detection.

\section{CONCLUSIONS}

With the considerations adopted in this computational model, it was not possible to detect a tumor of up to $2.0 \mathrm{~mm}$ in radius, located in the tongue through a thermal analysis of its surface. This could happen because the analyzed organ is located inside the body, the temperatures of the tissue and surrounding regions are close to tumor temperatures. It can justify non-significant modification in the temperature profile.

An early diagnosis of a tumor using thermography as a screening tool would only be possible if the tumor heat generation rate was considerably higher, as it has been demonstrated in this work. Nevertheless, more studies will be needed to advance in this topic, in other conditions not studied here, variable boundary conditions, real geometries and also for different tumor locations. 


\section{REFERENCES}

BEZERRA, Luciete Alves. Uso de imagens termográficas em tumores mamários para validação de simulação computacional. 2007. 73 f. Dissertação (Mestrado em Engenharia Mecânica) - Universidade Federal de Pernambuco, Recife. 2007.

CAMARGO, Antônio Cândido. Câncer de boca e garganta. Disponível em: http://www.accamargo.org.br/tudo-sobre-o-cancer/boca-e-garganta/1/. Acesso em: $01 \mathrm{de}$ dezembro de 2017.

CHAKRABORTY, Mrityunjoy. et al. A new approach of oral cancer detection using bilateral texture features in digital infrared thermal images. In: Engineering in medicine and biology society (EMBC), 2016 IEEE 38th Annual International Conference of the. IEEE, p. 13771380, 2016.

COHEN, Ezra E. W. et al. Study of functional infrared imaging for early detection of mucositis in locally advanced head and neck cancer treated with chemoradiotherapy. Oral Oncology, v. 49, n. 10, p. 1025-1031, 2013.

COIMBRA, Filipe et al. Carcinoma do bordo da língua em fase inicial: apresentação de dois casos clínicos. Revista Portuguesa de Estomatología, Medicina Dentária e Cirurgia Maxilofacial, v. 52, n. 2, p. 77-82, 2011.

COLLINS, Louise. M. C.; DAWES, Colin. The surface area of the adult human mouth and thickness of the salivary film covering the teeth and oral mucosa. Journal of Dental Research, v. 66, n.8, p. 1300-1302, 1987.

CREZEE, J. et al. The theoretical and experimental evaluation of the heat balance in perfused tissue. Physics in Medicine \& Biology, v. 39, n. 5, p. 813, 1994.

CONSELHO NACIONAL DE ODONTOLOGIA DE GOIANIA - CRO-GO. Câncer Bucal no Brasil. Disponível em: http://www.crogo.org.br/index.php/noticias/258-cancer-bucalcresce-no-brasil. Acesso em: 24 de novembro de 2017.

DE MOURA, Sergio Adriane Bezerra. et al. Valor diagnóstico da saliva em doenças orais e sistêmicas: uma revisão de literatura. Pesquisa Brasileira em Odontopediatria e Clínica Integrada, Campina Grande, v. 7, n. 2, p. 187-194, 2007.

DE SOUZA, Remo Magalhães. O método dos elementos finitos aplicado ao problema de condução de calor. Apostila, Universidade Federal do Pará, Belém, 2003.

FERNÁNDEZ-CUEVAS, Ismael et al. Classification of factors influencing the use of infrared thermography in humans: A review. Infrared Physics \& Technology, v. 71, p. 28$55,2015$.

HADDAD, Denise S. et al. A new evaluation of heat distribution on facial skin surface by infrared thermography. Dentomaxillofacial Radiology, v. 45, n. 4, p. 3-10, 2016. 
ABREU, Amanda Isabella; LIMA, Thiago Parente; MEIRELES, Agnes Batista; SOUZA, Bárbara

HIROTA, Silvio K.; MIGLIARI, Dante Antonio; SUGAYA, Norberto Nobuo. Oral squamous cell carcinoma in a young patient: Case report and literature review. Anais Brasileiros de Dermatologia, Rio de Janeiro, v. 81, n. 3, p. 251-254, 2006.

INCROPERA, Frank P.; DE WITT, David P. Fundamentos de transferência de calor e massa. 6. ed. Rio de Janeiro: LTC, 2008. 643 p.

IT IS FOUNDATION. Database at a Glance. Disponível em: https://itis.swiss/virtualpopulation/tissue-properties/database/. Acesso em: 06 de fevereiro de 2018.

LÓPEZ, Mário; LAURENTYS-MEDEIROS, J. Semiologia médica: as bases do diagnóstico clínico. 5. ed. Rio de Janeiro: Revinter, 2004. 1233 p.

MADEIRA, Miguel Carlos; LEITE, Horacio Faig; RIZZOLO, Roelf Justino Cruz. "Anatomia da cavidade oral", p. 25-60. In: Sistema digestório: integração básico-clínica. São Paulo:

Blucher, 2016.

MINISTÉRIO DA SAÚDE, SECRETARIA DE ATENÇÃO À SAÚDE, INSTITUTO NACIONAL DE CÂNCER - INCA. A situação do câncer no Brasil. Rio de Janeiro, 2006.

MOREIRA, José Roberto Simões. Processos de Transferência de Calor. SISEA Laboratóro de Sistemas Energéticos Alternativos. 2012. Escola Politécnica da USP.

PAIVA, Rogério Ribeiro de et al. Ressonância magnética no diagnóstico do câncer de boca: revisão da literatura e relato de caso. Revista de Clínica e Pesquisa Odontológica, Curitiba, v. 5, n. 2, p. 129-134, 2009.

PARK, Kil Jin; ALONSO, Luís Felipe Toro; NUNES, Alexandre Sznelwar. Determinação experimental da condutividade e difusividade térmica de grãos em regime permanente.

Ciência e Tecnologia de Alimentos, Campinas, v. 19, n. 2, p. 264-269, 1999.

SANDERS, Ira; MU, Liancai. A three-dimensional atlas of human tongue muscles. The Anatomical Record, v. 296, n. 7, p. 1102-1114, 2013.

SCHWARTZ, R. G. et al. Guidelines for neuromusculoskeletal thermography. Thermology international, v. 16, n. 1, p. 5-9, 2006.

SILVA, José Duarte da. Modelagem computacional dos efeitos da termoterapia transpupilar em tumores oculares através do método dos volumes finitos em malhas não estruturadas. 2012. 174 f. Tese (Doutorado em Engenharia Mecânica) - Universidade Federal de Pernambuco, Recife. 2012.

SILVA, Anderson Spinelli Valdevino da. Classificação e segmentação de termogramas de mama para triagem de pacientes residentes em regiões de poucos recursos médicos. 2015. 94 f. Dissertação (Mestrado em Engenharia Mecânica) - Universidade Federal de Pernambuco, Recife, 2015. 


\section{DADOS DOS AUTORES}

\section{Amanda Isabella Abreu}

E-mail: amanda.isabella.abreu@gmail.com

Currículo Lattes: http://lattes.cnpq.br/7895325331017039

Engenheira Mecânica e Bacharel em Ciência e Tecnologia pela Universidade federal dos Vales do Jequitinhonha e Mucuri (UFVJM). Durante a graduação, foi monitora de fenômenos mecânicos, participei de projeto de extensão, IC com pesquisa voltada para termografia, membro da equipe Baja e da Empresa Jr. Gama Pensamento estratégico, representante discente no Colegiado do curso Engenharia Mecânica.

\section{Thiago Parente Lima}

E-mail: thiagopl@ict.ufvjm.edu.br

Currículo Lattes: http://lattes.cnpq.br/0351523541967126

Doutorado em Engenharia Mecânica pela Universidade Estadual de Campinas (UNICAMP), mestrado em Engenharia Mecânica pela Universidade Federal de Pernambuco (UFPE) e graduação em Engenharia Mecânica pela Universidade Federal da Paraíba (UFPB). Tem experiência na área de Engenharia Mecânica atuando principalmente nos seguintes temas: energias renováveis e transferência de calor.

\section{Agnes Batista Meireles}

E-mail: agnesabm@gmail.com

Currículo Lattes: http://lattes.cnpq.br/0450328743529819

Pós-doutoranda do Programa de Pós Graduação em Ciências Farmacêuticas da UFVJM atuando no Laboratório de Imunologia. doutorado e mestradado em Bioengenharia, graduação em Odontologia pela Universidade Federal de Minas Gerais (UFMG). Realizou estágio doutoral na Universidad de Zaragoza, Espanha.

\section{Bárbara Emanuella Souza}

E-mail: barbara.souza@eng.ox.ac.uk

Currículo Lattes: http://lattes.cnpq.br/9843976850146123

Bacharelado em Ciência e Tecnologia - ênfase em Ciência dos Materiais e Cálculo Diferencial e Integral UFVJM. Atualmente, está no último semestre de Engenharia Mecânica (2014-2017) também pela UFVJM. Durante a graduação, foi bolsista do programa Ciência sem Fronteiras na modalidade Graduação Sanduíche no Exterior (2014-2015) Edital n.143/2013 na University of California - San Diego (Estados Unidos).

\section{Libardo Andrés González Torres}

E-mail: 1.gonzales@ict.ufvjm.edu.br

Currículo Lattes: http://lattes.cnpq.br/5206093330545546

Pós-doutorado em Biomecânica no Departamento de Engenharia de Estruturas pela UFMG, doutorado em Mecânica Computacional pela Universidad de Zaragoza, mestrado em Matemática Aplicada e graduação em Engenharia Mecânica pela Universidad Nacional de Colombia - Bogotá. 